\title{
Media społecznościowe jako źródło informacji bibliograficznej w naukach humanistycznych. Komunikat z badań
}

\author{
Piotr Tafiłowski \\ Katedra Informatologii, Wydziat Dziennikarstwa, Informacji i Bibliologii, Uniwersytet Warszawski
}

\begin{abstract}
Abstrakt
Cel/teza: Celem artykułu jest przedstawienie wyników pilotażowego badania dotyczącego pewnych elementów zachowań informacyjnych humanistów, pracowników naukowych polskich uczelni, w sieciach społecznościowych. Chodzi o wykorzystywanie ich jako źródła informacji bibliograficznej w zakresie nowych publikacji we własnej dyscyplinie.

Koncepcja/metody badań: Pilotażowe badanie sondażowe tego typu zachowań informacyjnych przeprowadzone zostało w maju 2016 r. za pomocą ankiety udostępnionej na Facebooku i skierowanej do polskich badaczy humanistyki lub nauk społecznych. Przeprowadzono także wyszukiwanie artykułów zagranicznych poświęconych tej problematyce, by przedstawić światowy stan badań tej problematyki i na tym tle zarysować sytuację w Polsce.

Wyniki i wnioski: Badacze zagraniczni zgodni są co do tego, że korzystanie przez naukowców z mediów społecznościowych zwiększa liczbę cytowań oraz podnosi ogólny wpływ społeczny akademików aktywnie korzystających z tej formy popularyzacji. Wyniki badania sondażowego przeprowadzonego wśród badaczy polskich pokazały, że coraz chętniej korzystają oni z mediów społecznościowych poszukując informacji oraz tworząc sieci kontaktów. Nadal jednak możliwości oferowane przez nowe nowe media nie są w pełni wykorzystywane.

Oryginalność/wartość poznawcza: W Polsce nie prowadzono dotychczas badań nad tą formą nieformalnych zachowań komunikacyjnych pracowników wyższych uczelni.
\end{abstract}

\section{Słowa kluczowe}

Nieformalne zachowania komunikacyjne. Komunikacja naukowa. Niewidzialne kolegia. Sieci kontaktów. Dzielenie się informacją i wiedzą. Media społecznościowe. Nauka 2.0.

Otrzymany: 10 lipca 2016. Z Zrecenzowany: 15 lipca 2016. Zaakceptowany: 18 lipca.2016.

\section{Wprowadzenie}

Problematyka współczesnej komunikacji naukowej, a w jej ramach dzielenia się informacją i wiedzą, była już niejednokrotnie badana i omawiana w literaturze informatologicznej (z nowszej literatury polskiej zob. np. Świgoń, 2015; Kotuła, 2013; Nahotko, 2010; Sapa, 2009; Krakowska, 2008; Cisek \& Sapa, 2007. Tam też dalsze odsyłacze bibliograficzne). Współcześnie komunikacja naukowa coraz częściej wykorzystuje nowe technologie, przenosząc się do świata wirtualnego oraz nabiera cech zachowań nieformalnych (zob. Genoni et al., 2014; Nahotko, 2008, 171-175; Barjak, 2006; Genoni et al., 2005. Warto również zwrócić uwagę na książkę Baykoucheva, 2015, poświęconą różnorakim zagadnieniom zbierania informacji 
i zarządzania nimi w środowisku cyfrowym). Tematyce obiegu informacji w epoce nowych nowych mediów poświęciło swoje dysertacje doktorskie kilkoro informatologów młodego pokolenia. Przedmiot bibliografii w zmieniającym się środowisku informacyjnym badał Jarosław Pacek (Pacek, 2010), przy czym, jak sądzę, po upływie kilku już lat od publikacji jego książki refleksji należy poddać również rolę bibliografii w środowisku sieci społecznościowych. Przedmiotem analizy stać się powinna także funkcja bibliotek i placówek informacyjnych jako szeroko pojętych brokerów informacji bibliograficznej 2.0 (Gmiterek, 2012; Wójcik, 2013). Na zagadnienie konwergencji komunikacji naukowej zwrócił uwagę m.in. Emanuel Kulczycki (2012). Sieci społeczne naukowców korzystających z jednego z najpopularniejszych serwisów społecznościowych poddali analizie Veslava Osińska i Tomasz Komendziński (Osińska \& Komendziński, 2014, 269-280). Przedmiotem ich zainteresowania była jednak wizualizacja sieci kontaktów, a nie sposób dzielenia się wiedzą w tejże sieci.

W sieciach społecznościowych zachodzi dwukierunkowe (czy może raczej: wielokierunkowe) dzielenie się informacją. Każdy użytkownik może być nie tylko odbiorcą, ale też nadawcą oraz bardzo często pośrednikiem (brokerem) informacji przesyłanej różnymi kanałami, a także przenoszonej z jednego kanału informacyjnego do innego. Dzielenie się wiedzą przez pracowników naukowych w sieciach społecznościowych może przyjmować różne formy: prowadzenia blogów naukowych, dyskusji na forach, redagowania haseł w Wikipedii (czy ogólniej: aktywności w serwisach typu Wiki), zamieszczania wpisów na Twitterze czy Facebooku, udostępniania preprintów artykułów w społecznościowych serwisach naukowych itd. Rozwój nowych technologii umożliwia także włączanie się do dyskursu naukowego szeroko pojętym „amatorom” - osobom zainteresowanym daną problematyką, nieposiadającym jednak (jeszcze) stopni naukowych, stanowiska akademickiego czy ugruntowanej pozycji w środowisku naukowym (m.in. studentom i doktorantom).

Z powodu szybkiego przyrostu liczby publikacji naukowych w każdej dyscyplinie (por. np. Nahotko, 2010, 37) ${ }^{1}$, coraz większym problemem staje się nie tylko kwestia ich przeczytania, ale nawet uzyskiwania na bieżąco informacji o ukazujących się nowościach, monografiach i artykułach w czasopismach czy tomach zbiorowych. Tradycyjne sposoby pozyskiwania informacji bibliograficznej na temat nowości (bibliografie, cytowania, recenzje) stają się z różnych względów nieefektywne. Opóźnienia w publikowaniu recenzji monografii w czasopismach naukowych sięgać mogą nawet dwóch lat, zaś rozrastające się w nieskończoność tradycyjne spisy bibliograficzne mogą być niewygodne w użyciu. Nie do przecenienia pozostają bezpośrednie kontakty osobiste pomiędzy uczonymi, ustna wymiana informacji co do potrzeb oraz stanu badań w danej dyscyplinie, w tym także informacji i opinii na temat nowo ukazujących się publikacji. Z oczywistych względów jednak skala i zasięg tego typu komunikacji są znacznie ograniczone. Potrzebujemy zatem nowych narzędzi czy też sposobów docierania do tego typu informacji, narzędzi i metod nie tylko szybkich, ale też precyzyjnych. Konieczna wydaje się realizacja postulatów zarówno konstruowania nowych instrumentów, opartych na nowych technologiach, jak i personalizacji

\footnotetext{
${ }^{1}$ Jeden z respondentów przeprowadzonej przeze mnie ankiety, której wyniki omówione są w dalszej części artykułu, napisał: „Podstawowym problemem jest zachwianie proporcji między nowymi publikacjami a czasem możliwym nie tylko na ich przeczytanie, ale twórcze wykorzystanie - przemyślenie, zrobienie notatek, inspirację do własnych ścieżek badawczych". O nadprodukcji publikacji naukowych, których ilość zabija jakość oraz o konieczności ograniczenia liczby publikowanych artykułów, piszą Daniel Sarewitz (2016) i Lindsay Waters (2009).
} 
usług wyszukiwania informacji bibliograficznej (por. Machlarz 2014, 231-240). Takimi systemami filtrującymi mogą stać się w pewnym stopniu technologie zaliczane ogólnie do zjawisk określanych mianem Web 2.0 (definicje Web 2.0 zob. Gmiterek, 2012, 37-45; por. także Nahotko, 2010, 202-203. Na temat społeczności tworzących się wokół nowych serwisów zob. Jung, red., 2010). Mowa oczywiście nie o automatycznych filtrach personalizujących wyświetlane informacje, opartych na specjalnych algorytmach, takich jak te używane przez informatycznych gigantów (Facebook, Google, Amazon), choć takie również byłyby przydatne, lecz o świadomym i celowym konstruowaniu i kształtowaniu przez każdego użytkownika własnego środowiska informacyjnego. Proces ten polega na wyborze pewnych technologii, narzędzi czy kanałów, uznanych arbitralnie za najodpowiedniejsze, najwygodniejsze i w najlepszy sposób zaspokajające indywidualne potrzeby informacyjne, odrzuceniu zaś innych. W realiach społeczeństwa informacyjnego w coraz większym stopniu zmuszani jesteśmy, by przeistaczać się ze zwykłych konsumentów, użytkowników informacji, w graczy informacyjnych (Nicholas \& Dobrowolski, 2001, 4-7).

Wymienione powyżej zjawiska, wraz z zyskującym na popularności ruchem Open Access, należą w znacznej mierze do nieformalnych zachowań komunikacyjnych (Pikas, 2006). Przestrzeń wirtualna sprzyja tworzeniu się niewidzialnych kolegiów (ang. invisible colleges), czyli swego rodzaju nieformalnych grup uczonych z różnych instytucji, zazwyczaj odległych od siebie w przestrzeni geograficznej. John Gresham pisał o transformacji niewidzialnego kolegium, którego koncepcja powstała jeszcze w XVII stuleciu, do postaci kolegium cyfrowego, czy też kolegium w cyberprzestrzeni (ang. cyberspace college) (Gresham, 1994, 39). Znalazło to także oddźwięk w odpowiedzi jednej z respondentek omawianej poniżej ankiety, która stwierdziła, że nowe nowe media dają jej możliwość korzystania w pracy zawodowej z „konsultacji ze znanymi postaciami ze świata nauki”. Przy tym jednak wyłącznie od nastawienia samych akademików, członków owych kolegiów zależeć będzie, na ile, w jaki sposób i z kim zechcą oni dzielić się swoją wiedzą (będzie o tym mowa w dalszej części tekstu). Innymi słowy, dzięki technologiom sieciowym realizowany może być społecznościowy paradygmat uprawiania nauki, nazywany również niekiedy Nauką 2.0 (Cisek, 2008a; na temat koncepcji „nauki opartej na współpracy” zob. Tapscott \& Williams, 2008, 219-260).

\section{Problematyka badań}

Celem artykułu jest przedstawienie wyników pilotażowego badania dotyczącego pewnych elementów zachowań informacyjnych humanistów, pracowników naukowych polskich uczelni, w sieciach społecznościowych, a mianowicie wykorzystywania ich jako źródła informacji bibliograficznej w zakresie nowych publikacji we własnej dyscyplinie. Prowadzono już badania dotyczące narzędzi i źródeł informacji bibliograficznej wykorzystywanych przez polskich pracowników naukowych (ich wyniki nie zostały jeszcze dotychczas opublikowane, choć mówiono o nich w czasie konferencji „Nauka o informacji (informacja naukowa) w okresie zmian", zorganizowanej przez IINiSB Uniwersytetu Warszawskiego 11-12 maja 2015 r.). Problemowi temu poświęcona została także książka Anny Mierzeckiej-Szczepańskiej, która podjęła się studiów nad zachowaniami informacyjnymi pracowników Wydziału Historycznego Uniwersytetu Warszawskiego. Zgodnie z jej ustaleniami: 
naukowcy zbierający informacje w pierwszej kolejności korzystają z komunikacji nieformalnej, wymiany informacji wśród kolegów specjalistów o prowadzonych pracach badawczych z danego zakresu, a dopiero później sięgają do źródeł formalnych (Mierzecka-Szczepańska , 2013, 123-124).

Jednakże społecznościowy aspekt tego zagadnienia nie był dotychczas analizowany przez polskich specjalistów, aczkolwiek nie ulega wątpliwości, że włączenie go do badań nad nieformalnymi zachowaniami informacyjnymi pracowników nauki, jako integralnej części tego zjawiska, staje się niezbędne. Fakt ten już przed kilku laty uświadomili sobie badacze z krajów anglosaskich. Przykładowo, problem dzielenia się wiedzą ukrytą za pomocą narzędzi społecznościowych stanowił przedmiot analizy akademików australijskich: Sirousa Panahiego, Jasona Watsona oraz Helen Partridge (Panahi et al., 2013; Panahi et al., 2012). Z kolei międzynarodowa grupa specjalistów zaproponowała analizę śladów zachowań informacyjnych naukowców w sieciach społecznościowych, ich elektronicznych aktów komunikacyjnych oraz rozpatrywanie ich jako tzw. wskaźników altmetrycznych. Jak piszą:

Termin ten można zdefiniować jako tworzenie i badanie nowych wskaźników wptywu opartych o media społecznościowe, stużących analizowaniu aktywności w szkolnictwie wyższym. Wskaźniki altmetryczne ilustrują aspekt zmieniających się procesów naukowo-badawczych, dialog i wykorzystanie wyników badań. Wskaźniki altmetryczne pokazują także zmieniające się metody bibliometryczne i naukometryczne (Puckett Rodgers \& Barbrow, 2014, 2) 2 .

Na temat aktywności naukowców w serwisach społecznościowych pisał w Nature Richard Van Noorden (Van Noorden, 2014). Cytaty można by mnożyć. Oczywiste staje się zatem, że studia na tym polu podjąć muszą także polscy informatolodzy.

\section{Wykorzystanie Web 2.0 przez humanistów - wyniki badań pilotażowych}

Pilotażowe badanie tego typu zachowań informacyjnych przeprowadzono w maju 2016 r., rozsyłając ankietę składającą się z sześciu pytań (zob. załącznik). Choć prośba o jej wypełnienie w samym tylko serwisie Facebook dotarła - zgodnie z dostępnymi statystykami - co najmniej do 2500 użytkowników, ostatecznie zdecydowały się ją wypełnić jedynie 42 osoby, 20 mężczyzn i 22 kobiety. Wśród nich były dwie osoby z dyplomem studiów licencjackich, 25 - magisterskich, 10 osób z doktoratem oraz pięcioro doktorów habilitowanych. Największy odsetek respondentów stanowili reprezentanci bibliologii i informatologii (18 osób) oraz historii (12 osób). Ankietę wypełniło także troje historyków sztuki oraz pojedynczy reprezentanci pedagogiki, filologii klasycznej, archeologii, sztuk pięknych, etnologii, nauk o polityce, socjologii, kulturoznawstwa, językoznawstwa oraz literaturoznawstwa. Największą popularnością wśród nich cieszą się serwisy: Facebook (39 użytkowników), Academia. edu (23 użytkowników), Lubimyczytac.pl (14), Researchgate.net i Mendeley (po 7 wskazań), a wreszcie Biblionetka.pl oraz Twitter (po 5 wskazań). Jaki obraz nieformalnej komunikacji naukowej w mediach społecznościowych wyłania się z tego badania?

Stosunkowo najwięcej zainteresowania badaczy zajmujących się współczesną komunikacją naukową wzbudzają prowadzone przez naukowców blogi (zob. np. Kulczycki, 2012; Cisek, 2008b, 170-177; Kjellberg, 2009) - prawdopodobnie dlatego, że najłatwiej poddają

\footnotetext{
${ }^{2}$ Zob. też Priem et al., 2012; Priem et al., 2011.
} 
się obserwacji i opisowi. Powyżej wspomniałem już o recenzjach, będących w tradycyjnym systemie komunikacji naukowej jednym ze źródeł informacji o nowych (choć może już nie najnowszych) publikacjach. W danym kontekście stwierdzić trzeba, że recenzja książki naukowej opublikowana na blogu ma tę przewagę nad recenzją w czasopiśmie, że nie tylko ma szanse ukazać się szybciej, lecz także potencjalnie posiada większy zasięg, być może przeczyta ją (a przynajmniej do niej dotrze) więcej czytelników niż do tekstu drukowanego. Ponadto będą oni mogli także wyrazić swoje opinie, podać uzupełnienia (także bibliograficzne), sprostowania czy w komentarzach zadać dodatkowe pytania autorowi recenzji.

W drugiej połowie XX w. recenzje i abstrakty były jednymi z filarów rozwoju nauki w Polsce (szczególnie w przypadku niedostępnej literatury zagranicznej). Jednakże wraz ze zmianą rzeczywistości społeczno-politycznej, stanowiącej otoczenie nauki, a także samej nauki i funkcjonującej w jej ramach komunikacji, również i rola recenzji naukowych musiała ulec zmianie. Obecnie w poszukiwaniu informacji, także tej o krajowych i zagranicznych nowościach wydawniczych, sięga się po źródła i narzędzia innego rodzaju niż jeszcze dwie dekady temu. Zresztą proces publikacji czasopism trwa na tyle długo, że recenzowana książka często zdąży zniknąć z półek księgarskich, zanim jej recenzja ukaże się drukiem.

Wszystko to sprawia, że wielu pracowników naukowo-dydaktycznych, lecz także amatorów, wierzy w sens wykorzystania narzędzi społecznościowych, w tym platform blogowych (zarówno ogólnych, jak i specjalistycznych platform dedykowanych dla blogów naukowych, na przykład ScienceBlogs czy ResearchBlogging), w celu pisania o książkach i artykułach naukowych, recenzowania i dyskutowania o nich. Teksty na blogach naukowych różnią się od tych publikowanych na blogach literackich m.in. tym, że nie powstają w celach marketingowych. Już samo czytanie dobrze napisanej, rzetelnej recenzji dać może sporo wiadomości, rzucać nowe światło na znane problemy, pozwala spojrzeć na nie z innej perspektywy, podsunąć nowe interpretacje, zachęcać do własnych przemyśleń. Nauka rozwija się w dialogu, nie w monologu, jakim jest opublikowanie książki czy artykułu, a blogujący recenzenci włączają się w debatę i zachęcają do tego innych. Teraz, gdy na publikację odpowiedzi autorowi recenzji nie trzeba czekać do następnego numeru czasopisma (ukazującego się co kwartał lub rzadziej) dialog ten toczyć się może o wiele łatwiej i skuteczniej. Także wielu z respondentów uważa blogi za istotne źródło informacji o nowych publikacjach, jak na przykład „blogi specjalistyczne prowadzone przez informatologów i bibliotekarzy”.

Drugim ważnym medium społecznościowym, często omawianym w kontekście zastosowań w komunikacji naukowej, są mikroblogi. Analizie poddaje się możliwości wykorzystania ich (w szczególności dotyczy to popularnego Twittera) w celu promowania publikacji naukowych. W Polsce Twitter wciąż nie cieszy się zbyt wielkim uznaniem w środowiskach akademickich (jak wspomniano, zaledwie pięć wskazań w ankiecie), inaczej natomiast jest w Ameryce Północnej, gdzie pracownicy wyższych uczelni korzystają z niego dość intensywnie. Szczególnie wiele interesujących wiadomości na ten temat zawiera artykuł Gunthera Eysenbacha, który zaproponował nowatorskie ujęcie naukometryczne z wykorzystaniem nowego źródła danych, czyli właśnie Twittera. Serwisu tego użyć można do pomiaru oddziaływania społecznego publikacji, uzupełniając tradycyjną analizę cytowań. Badania kanadyjskiego uczonego dowodzą, że tweetowanie na temat artykułów naukowych może wielokrotnie zwiększyć ich zasięg społeczny oraz liczbę cytowań. Podkreśla on także, że ocena naukometryczna wpisów zamieszczanych w mediach społecznościowych (ang. social media impact metrics) jest problemem ważnym z kilku powodów. Po pierwsze, może 
być dość łatwo stosowana przez samych akademików, instytucje i redakcje czasopism celem kontrolowania ogólnego wpływu społecznego konkretnych badań w wybranych przedziałach czasowych. Po drugie, dzięki tej metodzie można poddawać ewaluacji różne metody upowszechniania wiedzy. Po trzecie wreszcie, może ona znaleźć zastosowanie jako narzędzie, dzięki któremu będzie można kierować czytelników do tych artykułów, które w największym stopniu przyciągają uwagę publiczności czy też społeczności uczonych (Eysenbach, 2011). Przydatność praktycznego zastosowania tego serwisu mikroblogowego dla udostępniania informacji o nowych publikacjach, powiększania grona odbiorców tekstów oraz jako narzędzia naukometrycznego, powalającego śledzić impact factor własnych publikacji, podkreślają także autorzy poradnika Using Twitter in University Research, Teaching and Impact Activities (Mollett et al., 2011). Co ciekawe, badacze, którzy zadali sobie pytanie, czy wskaźniki altmetryczne rzeczywiście działają, doszli do wniosków negatywnych. Nie dostrzegli oni znaczących korelacji pomiędzy wpisami w serwisach społecznościowych a wzrostem liczby cytowań. Mimo to wskazali na wyjątkową, pozytywną pozycję Twittera w tym kontekście (Thelwall et al., 2013) ${ }^{3}$.

Bez wątpienia ze wszystkich społecznościowych kanałów komunikacyjnych to właśnie Twitter doczekał się najgłębszej refleksji naukometrycznej, komunikologicznej i informatologicznej. Jak już wspomniano, u nas nie cieszy się on takim powodzeniem, jak za Oceanem i dotychczas niewielu polskich naukowców z niego korzysta. W warunkach polskich serwis ten wykorzystywany jest głównie przez polityków i dziennikarzy, natomiast przeciętnych użytkowników posiada stosunkowo niewielu.

Doskonałym miejscem udostępniania informacji o nowych publikacjach wydaje się być serwis Facebook. Podkreślało to wielu z respondentów ankiety. Komunikacja taka odbywać się może na różne sposoby: w grupach, zarówno o tematyce ogólnej (np. „Publikacje humanisty”), jak i specjalistycznych, fachowych czy zawodowych (np. „Biblio”, „Mediewiści polscy”, "Imago Turci”; czasem użytkownicy publikują w grupach nie tylko informacje o nowych książkach, polskich i zagranicznych, lecz także spisy treści wydawnictw zbiorowych czy najnowszych numerów czasopism), poprzez profile wydawców (bardzo wiele wydawnictw naukowych posiada już swoje profile w serwisach społecznościowych i mniej lub bardziej systematycznie udostępnia na nich informacje na temat nowości wydawniczych) czy też „brokerów informacji bibliograficznej” (np. „Classica, mediaevalia et cetera”, „New Books in History”, „Libros arte medieval”). Informacje o nowych książkach publikują czasem także na swoich profilach sami autorzy, jak również jednostki naukowe, w których są zatrudnieni (katedry, instytuty czy wydziały wyższych uczelni), a wreszcie różnego rodzaju instytucje (np. archiwa, muzea, biblioteki naukowe). Dzięki polubieniom i udostępnieniom informacja taka potencjalnie docierać może do tysięcy użytkowników.

Zauważyć trzeba, że zamknięte grupy specjalistyczne, takie jak wspomniane powyżej, niekiedy wykazują tendencję do wykluczania amatorów, osób spoza ścisłego środowiska zawodowego (a także spoza własnych kręgów towarzyskich), jednakże zainteresowanych problematyką. Dążą do elitarności, a tym samym nie wykorzystują szansy na szersze upowszechnienie wyników badań swojej dyscypliny czy popularyzację nauki w ogóle. Zjawisko to ocenić należy zdecydowanie negatywnie, ponieważ popularyzacja jest jednym

${ }^{3}$ Korpus literatury anglojęzycznej poświęconej naukowemu tweetowaniu jest już pokaźny. W tym miejscu warto przywołać jeszcze jeden tylko artykuł: Holmberg \& Thelwall, 2013. 
z obowiązków pracowników nauki, szczególnie tych korzystających z mediów społecznościowych. O konieczności wykorzystywania tychże przez uczonych w celu popularyzacji nauki pisała w 2011 r. na swoim blogu w witrynie „Scientific American” Christine Wilcox (Wilcox, 2011). Na problem niechęci naukowców do popularyzacji nauki, wynikającej z ich obaw przed utratą naukowej powagi („saganizacji”), zwróciła uwagę m.in. grupa amerykańskich medioznawców i komunikologów (Liang et al., 2014, 772-775). Równocześnie autorzy ci wskazali, że rozwój technologii informatycznych daje uczonym nowe możliwości docierania do różnych kręgów opinii publicznej i aktywnego kształtowania form komunikacji oraz sformułowali hipotezę, zgodnie z którą istnieje pozytywna korelacja pomiędzy komunikowaniem się badaczy z publicznością spoza świata nauki a wpływem naukowym (ang. scientific impact) akademików posiadających tę umiejętność. Uczeni, którzy angażują się w działania popularyzujące naukę, publikują więcej artykułów w czasopismach recenzowanych i bywają częściej cytowani ${ }^{5}$.

Facebook cieszy się największą popularnością wśród respondentów ankiety (korzysta z niego niemal 93\% badanych), choć w pewnej mierze wynik ten może być spowodowany faktem, że prośbę o udział w badaniu rozsyłałem za pomocą tego serwisu, licząc na efekt wirtualnej kuli śnieżnej (co już samo w sobie jest dość symptomatyczne; wspomniałem powyżej, iż media społecznościowe coraz częściej wykorzystywane są do prowadzenia badań naukowych). Jak napisał jeden z respondentów, profesor nadzwyczajny Uniwersytetu Adama Mickiewicza w Poznaniu, „Korzystam z fb. Mam polubione strony kilku wydawnictw i na bieżąco pojawiają mi się informacji o nowościach, szczególnie z interesujących mnie dziedzin. Obserwuję również profile znajomych naukowców, którzy często podają informacje o nowościach wydawniczych”. Inny badany chwali, że Facebook umożliwia mu „zbieranie wszelkich możliwych nowinek historycznych”. Kolejna respondentka wyznaje: „gdyby nie różne grupy, nie korzystałabym z tego [serwisu] - nie mam czasu na 'zabawy' w czytanie nieinteresujących rzeczy. Jedynie sprawy związane z nauką, nowymi publikacjami, badaniami, eventami kulturalnymi etc. To trzeba przyznać - jest [to] dobre źródło informacji”.

Dobrym sposobem społecznościowego udostępniania informacji bibliograficznej są fora tematyczne. Dają one użytkownikom możliwość wymieniania się informacjami na temat nowości, ale także uzupełniania własnych spisów o pozycje dawniejsze, a dotychczas nieznane, polecane przez innych forumowiczów. Interesujący wydaje się przykład publikującego książki historyczne oświęcimskiego wydawnictwa Napoleon V, którego właściciel jest aktywnym użytkownikiem największego forum historycznego w Polsce - historycy. org. Za jego pośrednictwem komunikuje się ze swoimi czytelnikami: zbiera informacje na temat ich oczekiwań, pozycji, których brakuje na polskim rynku, rekomendacji zagranicznej literatury etc. Ponadto na subforum wydawniczym otwiera w nowych wątkach dyskusje nad ostatnio opublikowanymi książkami. Użytkownicy zatem nie tylko bardzo szybko dowiadują się o nowościach wydawniczych, lecz także mają możliwość podyskutowania o nich, wymienienia się opiniami, jak też kształtowania polityki wydawniczej. Dla wydawcy

\footnotetext{
${ }^{4}$ Termin ukuto od nazwiska amerykańskiego astronoma i popularyzatora nauki, Carla Edwarda Sagana, który z powodu swojego zaangażowania w działalność popularyzatorską stracił autorytet naukowy w oczach swoich kolegów.

${ }^{5}$ Konieczność wykorzystywania mediów 2.0 podkreślana jest także przez wielu innych autorów. Przegląd odnośnej literatury dostępny jest online pod adresem https://socialnetworkingforscientists.wikispaces. com/General (dostęp: 27.05.2016).
} 
zaś jest to nie tylko forma promocji, lecz także platforma, na której może nawiązać kontakt $\mathrm{z}$ autorami czy tłumaczami, budując swoje sieci kontaktów.

Zarządzaniu własnymi zestawieniami bibliograficznymi, ale także dzieleniu się tego typu informacją z innymi użytkownikami, służą narzędzia zwane menedżerami bibliografii, takie jak Mendeley, Zotero, EndNote, Refworks czy CiteULike, te jednak nie są w Polsce zbyt popularne (Wiorogórska, 2015). Spośród badanych humanistów jedynie siedmiu wskazało, iż korzysta z Mendeley, nikt natomiast nie używa pozostałych. Trzeba na koniec wspomnieć także o społecznościowych repozytoriach tekstów naukowych, takich jak Academia. edu („jest genialna”) czy Researchgate.net (odpowiednio 23 i 7 użytkowników w badaniu ankietowym). Dają one możliwość nie tylko publikowania własnych tekstów naukowych, lecz także prowadzenia na ich temat dyskusji. Ich użytkownicy mogą tworzyć własne sieci kontaktów, obserwować wybrane osoby, a dzięki temu mogą na bieżąco dowiadywać się o ich nowych publikacjach.

Istotnym źródłem informacji stają się newslettery księgarń naukowych i specjalistycznych, których bazy danych

zwłaszcza za granicą, stają się ważnym darmowym źródłem informacji o produkcji wydawniczej (Jachimczyk, 2008, 245).

Z powiadomień różnego rodzaju korzysta znaczna część ankietowanych.

Uzupełniającym sposobem zdobywania informacji bibliograficznej mogą być popularne społecznościowe serwisy czytelnicze, np.Lubimyczytac.pl. Dokonywane tam przypadkowe odkrycia oraz rekomendacje innych użytkowników, obserwowanych i znajomych, mogą stanowić cenne uzupełnienie własnych zestawień bibliograficznych. Problematyka niezamierzonego pozyskiwania informacji o literaturze doczekała się już także refleksji w piśmiennictwie informatologicznym, a co więcej, postuluje się konstruowanie naukowych cyfrowych systemów informacyjnych nie tylko umożliwiających, ale wręcz

inspirujących przypadkowe odkrywanie informacji i relacji między nimi (Sapa, 2008, 81. Tam też literatura przedmiotu).

Obecnie uzasadniona jest aktualizacja tej obserwacji poprzez włączenie w jej zakres także bibliofilskich serwisów społecznościowych.

\section{Zakończenie}

Podsumowując powyższe rozważania, bazując nie tylko na wynikach pilotażowej ankiety, lecz także na obserwacjach zachowań informacyjnych moich koleżanek i kolegów w serwisach społecznościowych, których sam jestem użytkownikiem, stwierdzić trzeba, iż polscy humaniści coraz aktywniej wykorzystują owe media do poszukiwania informacji, w tym także informacji bibliograficznej (choć pięcioro respondentów udzieliło odpowiedzi, że nie korzysta z nich w tym celu w ogóle ${ }^{6}$ ). Warto podkreślić raz jeszcze, że udostępnianie za ich pomocą informacji o nowych publikacjach powoduje wzrost liczby cytowań oraz

\footnotetext{
${ }^{6}$ Jedna z badanych osób napisała: „Szczerze mówiąc, nie przyszło mi to jeszcze do głowy. Ale bardzo dziękuję za sugestię!".
} 
ogólnie podnosi poziom wpływu społecznego i naukowego (vulgo: popularność) obecnego w sieci uczonego. Nowe nowe media służą polskim humanistom zasadniczo do wymiany informacji o monografiach, rzadziej zaś powiadamia się za ich pośrednictwem o artykułach, choć niekiedy udostępniania się skany spisów treści nowych numerów czasopism lub też materiałów konferencyjnych, a także preprinty artykułów za pośrednictwem takich serwisów, jak Academia.edu.

Za swego rodzaju post scriptum do moich rozważań uznać można wyniki ankiety „W sieci o książkach", dotyczącej sposobów lektury Polaków, opublikowane 24 maja 2016 r. przez wspomniany serwis Lubimy Czytać 7 . W ankiecie wzięło udział bez mała 24 tys. respondentów - użytkowników serwisu i członków sieciowej społeczności czytelniczej. Sondaż ten wskazuje, jak ważnym medium stał się Internet dla miłośników literatury. Poszukują oni za jego pośrednictwem informacji o książkach, uczestniczą w dyskusjach, korzystają z mediów „dwuzerowych”, także tych poświęconych szczególnie tematyce literackiej i to one stanowią dla nich ważne źródło informacji na temat produkcji wydawniczej. Jako takie wymieniano tutaj m.in. Lubimy Czytać, strony księgarni internetowych, blogi i vlogi książkowe, Facebook, Twitter, Instagram itd.

Nie ulega zatem wątpliwości, że mamy do czynienia z istotnym, nabierającym - w miarę upowszechniania się technologii „dwuzerowych” w różnych dziedzinach życia - coraz większej wagi zjawiskiem społecznym, wartym pogłębionych badań i szerszego opisu. Jest to bardzo skomplikowany i pojemny treściowo fenomen, z wieloma mniej lub bardziej bezpośrednimi i oczywistymi implikacjami, w którego omówieniu trzeba odwoływać się do różnych zagadnień, umieszczając je w szerokim kontekście (przypomnijmy dla uporządkowania: nieformalne zachowania komunikacyjne w komunikacji naukowej, tworzenie niewidzialnych kolegiów oraz sieci kontaktów, dzielenie się informacją i wiedzą, rozwój nowych nowych mediów, społecznościowy paradygmat uprawiania nauki). Problem dotychczas pozostaje w Polsce raczej niezauważony, natomiast wiele uwagi poświęcają mu naukowcy z zachodniego kręgu kulturowego.

W gruncie rzeczy nie jest istotne, jakich technologii i mediów będziemy używali, by zaspokajać własne potrzeby informacyjne. Ważne jest, by wybrać sobie odpowiednie dla indywidualnych upodobań, potrzeb oraz realizacji stających przed nami zadań narzędzia i korzystać z nich rozbudowując sieci kontaktów, a przede wszystkim by świadomie zarządzać swoim środowiskiem informacyjnym, stając się ekspertem w „grze o informację”.

\section{Bibliografia}

Barjak, F. (2006). The Role of the Internet in Informal Scholarly Communication. Journal of the American Society for Information Science and Technology, 57 (10), 1350-1367.

Baykoucheva, S. (2015). Managing Scientific Information and Research Data. Amsterdam: Elsevier.

Cisek, S. (2008a). Nauka 2.0. Nowe narzędzia komunikacji naukowej [online]. e-LiS, [11.05.2016], http://eprints.rclis.org/11212/

Cisek, S. (2008b). Weblogi (blogi) - nowe narzędzie komunikacji w nauce. W: D. Pietruch-Reizes (red.) Zarzadzanie informacją w nauce. Katowice: Wydawnictwo Uniwersytetu Śląskiego, 170-177.

Cisek, S.; Sapa, R. (2007). Komunikacja naukowa w Internecie - mity i rzeczywistość. W: W. Lubaszewski (red) Komputer - Człowiek - Prawo. Kraków: Wydaw. UJ, 39-49.

\footnotetext{
${ }^{7}$ http://lubimyczytac.pl/aktualnosci/7122/w-sieci-o-ksiazkach---wyniki-ankiety.
} 
Eysenbach, G. (2011). Can Tweets Predict Citations? Metrics of Social Impact Based on Twitter and Correlation with Traditional Metrics of Scientific Impact. Journal of Medical Internet Research, 13 (4), [27.04.2016], http://www.jmir.org/2011/4/e123/

Genoni, P.; Merrick, H.; Willson, M. (2014). Virtual Symposia: An Investigation into Scholarly Communities Online [online]. Academia.edu, [18.05.2016], https://www.researchgate.net/publication/240636706_Virtual_symposia_an_investigation_into_scholarly_communities_online

Genoni, P.; Merrick, H.; Willson, M. (2005). Community, Communication, Collaboration: Scholarly Practice in Transformation. In: Proceedings of the Next Wave of Collaboration: Educause Australasia 2005, April 5-8, 2005 [online]. Auckland, NZ: Curtin Univeristy, [18.05.2016], http://espace. library.curtin.edu.au/R?func=dbin-jump-full\&local_base=gen01-era02\&object_id=19204

Gmiterek, G. (2012). Biblioteka w środowisku społecznościowego Internetu : biblioteka 2.0. Warszawa: Wydaw. SBP.

Gresham, J. (1994). From Invisible College to Cyberspace College: Computer Conferencing and the Transformation of Informal Scholarly Communication Networks. Interpersonal Computing and Technology Journal, 2 (4), 37-52.

Holmberg, K.; Thelwall, M. (2013). Disciplinary Differences in Twitter Scholarly Communication. In: J. Gorraiz; E. Schiebel; C. Gumpenberger; M. Hörlesberger; H. Moed (eds.) Proceedings of the 14th International Society of Scientometrics and Informetrics Conference, Vienna, Austria. Wien: Austrian Institute of Technology, 567-582.

Jachimczyk, A. (2008). Bazy internetowe księgarń jako źródło informacji. W: D. Pietruch-Reizes, W. Babik (red.) Wymiana informacji i rozwój profesjonalnych usług informacyjnych w edukacji, nauce i kulturze na rzecz społeczeństwa opartego na wiedzy. Katowice: PTIN, 245-253.

Jung, B. red. (2010). Wokót mediów ery Web 2.0. Warszawa: Wydaw. Akademickie i Profesjonalne.

Kjellberg, S. (2009). Blogs as Interface Between Several Worlds. A Case Study of the Swedish Academic Blogosphere. Human IT, 10 (3), 1-45.

Kotuła, S.D. (2013). Komunikacja bibliologiczna wobec World Wide Web. Lublin: Wydaw. UMCS.

Krakowska, M. (2008). Nowe formy komunikacji społecznej w europejskiej przestrzeni edukacyjnej. Kraków: Wydaw. UJ.

Kulczycki, E. (2012). Blogi i serwisy naukowe. Komunikacja naukowa w kulturze konwergencji. W: I. Sójkowska (red.) Materiały konferencyjne EBIB, 22. Toruń: Stowarzyszenie EBIB, [16.05.2016], https://repozytorium.amu.edu.pl/handle/10593/2520

Liang, X.; Su, L.Y.-F.; Yeo, S.K.; Scheufele, A.A.; Brossard, D.; Xenos, M.; Nealey, P.; Corley, E.A. (2014) Building Buzz: (Scientists) Communicating Science in New Media Environments. Journalism E Mass Communication Quarterly, 91 (4), 772-791.

Machlarz, A. (2014). Nadinformatywność systemów informacyjnych. W: E. Głowacka, M. Kowalska, P. Krysiński (red.) Wspótczesne oblicza komunikacji i informacji. Problemy, badania, hipotezy. Toruń: Wydaw. Nauk. UMK, 231-242.

Mierzecka-Szczepańska, A. (2013). Badania zachowań informacyjnych. Warszawa: Wydaw. SBP.

Mollett, A.; Moran, D.; Dunleavy P. (2011). Using Twitter in University Research, Teaching and Impact Activities [online]. LSE Research Online, [11.05.2016], http://eprints.lse.ac.uk/38489/1/ Using_Twitter_in_university_research\%2C_teaching_and_impact_activities_(LSE_RO).pdf

Nahotko, M. (2008) Czy nastąpi koniec druku? Komunikacja naukowa XXI wieku oparta na publikacjach elektronicznych. W: D. Pietruch-Reizes, W. Babik (red.) Wymiana informacji i rozwój profesjonalnych ustug informacyjnych w edukacji, nauce $i$ kulturze na rzecz społeczeństwa opartego na wiedzy. Katowice: PTIN, 78-91.

Nahotko, M. (2010). Komunikacja naukowa w środowisku cyfrowym: globalna biblioteka cyfrowa w informatycznej infrastrukturze nauki. Warszawa: Wydaw. SBP.

Nicholas, D.; Dobrowolski, Z. (2001). Informacyjny gracz: nowa koncepcja użytkownika informacji. Praktyka i Teoria Informacji Naukowej 1-2, 4-9. 
Osińska, V.; Komendziński, T. (2014). Naukowcy na Facebooku. Wizualizacja sieci społecznych w nauce. W: E. Głowacka, M. Kowalska, P. Krysiński (red.) Wspótczesne oblicza komunikacji i informacji. Problemy, badania, hipotezy. Toruń: Wydaw. Nauk. UMK, 269-282.

Pacek, J. (2010). Bibliografia w zmieniajacym się środowisku informacyjnym. Warszawa: Wydaw. SBP.

Panahi, S.; Watson, J.; Partridge, H. (2013). Towards Tacit Knowledge Sharing over Social Web Tools. Journal of Knowledge Management 17 (3), 379 - 397.

Panahi, S.; Watson, J.; Partridge, H. (2012). Social Media and Tacit Knowledge Sharing: Developing a Conceptual Model, World Academy of Science, Engineering and Technology 64, 1095-1102.

Pikas, Ch.K. (2006). The Impact of Information and Communication Technologies on Informal Scholarly Scientific Communication: A Literature Review [online]. University of Maryland, [11.05.2016], http://terpconnect.umd.edu/ cpikas/878/Pikas_The_Impact_of_ICTs_on_ISSC_0506.pdf

Priem, J.; Taraborelli, D.; Groth, P.; Neylon, C. (2012). Altmetrics: A Manifesto [online]. Altmetrics, [18.05.2016], http://altmetrics.org/manifesto

Priem, J.; Piwowar, H.A.; Hemminger, B.M. (2011). Altmetrics in the Wild: Using Social Media to Explore Scholarly Impact [online]. Altmettrics, [18.05.2016], http://altmetrics.org/altmetrics12/priem/

Puckett Rodgers, E.; Barbrow, S. (2014). Wskaźniki altmetryczne i ich rosnące znaczenie w bibliotekach naukowych [online], Biuletyn EBIB, 6 (151), [18.05.2016], http://open.ebib.pl/ojs/index. php/ebib/article/view/249

Sapa, R. (2009). Metodologia badań obszaru pośredniczenia w komunikacji naukowej z perspektywy nauki o informacji. Kraków: Wydaw. UJ.

Sapa, R. (2008). Przypadkowe pozyskiwanie informacji o literaturze naukowej. Inne spojrzenie na jakość systemów informacyjnych dla naukowców. W: D. Pietruch-Reizes, W. Babik (red.) Wymiana informacji i rozwój profesjonalnych usług informacyjnych $w$ edukacji, nauce i kulturze na rzecz społeczeństwa opartego na wiedzy. Katowice: PTIN, 77-85.

Sarewitz, D. (2016). The Pressure to Publish Pushes Down Quality [online]. Nature, 533 (12 May 2016), [18.05.2016], http://www.nature.com/news/the-pressure-to-publish-pushes-down-quality-1.19887?

Świgoń, M. (2015). Dzielenie się wiedza i informacją : specyfika nieformalnej komunikacji w polskim środowisku akademickim. Olsztyn: Wydaw. UWM.

Tapscott, D.; Williams, A.D. (2008). Wikinomia: o globalnej wspótpracy, która zmienia wszystko. Warszawa: Wydaw. Akademickie i Profesjonalne.

Thelwall, M.; Haustein, S.; Larivière, V.; Sugimoto, C.R. (2013). Do Altmetrics Work? Twitter and Ten Other Social Web Services [online]. PLOS, [18.05.2016], http://dx.doi.org/10.1371/journal. pone.0064841

Van Norden, R .(2014). Online Collaboration: Scientists and the Social Network [online]. Nature, 512 (14 August 2014), [18.05.2016], http://www.nature.com/news/online-collaboration-scientistsand-the-social-network-1.15711

Waters, L. (2009). Zmierzch wiedzy. Przemiany uniwersytetu a rynek publikacji naukowych. Kraków: Homini.

Wilcox, C. (2011). Social Media for Scientists. Part 1: It's Our Job [online]. Scientific American [11.05.2016], http://blogs.scientificamerican.com/science-sushi/social-media-for-scientists-part-1-it-8217-s-our-job/

Wiorogórska, Z. (2015). Field-Specific Information Needs of Doctoral Students in Psychology. A Comparative Study. In: S. Kurbanoglu, J. Boustany, S. Spiranec, E. S. Grassian, D. Mizrachi, \& L. Roy (eds.) Information Literacy: Moving Toward Sustainability. Third European Conference, ECIL 2015, Tallinn, Estonia, October 19-22, 2015, Revised Selected Papers. Springer International Publishing Switzerland, 375-382.

Wójcik, M. (2013). Web 2.0 w działalności ustugowej instytucji książki. Kraków: Wydaw. UJ. 


\title{
Social Media as a Source of Bibliographic Information in the Humanities. Research Report
}

\begin{abstract}
Purpose/Thesis: The purpose of this paper is to present the results of a pilot study on selected elements of information behavior of Polish humanists (academic staff of Polish universities) observed in social networks. The central idea is to analyze the use of the social networks as a source of bibliographic information on new publications in a given field of science. .

Approach/Research methods: The pilot study of this type of information behavior was conducted in May 2016 with a questionnaire made available on Facebook and addressed to Polish scholars in the humanities and social sciences. Moreover, the research was made to find foreign articles devoted to this issue in order to reflect a global state of research on this subject, using it as a background to outline the state of respective research in Poland.

Results and conclusions: Foreign researchers are unanimous in recognizing the use of the social media as the factor increasing the number of citations and improving the overall social impact of scholars actively applying this form of knowledge popularization. Polish scientists are increasingly eager to use social media while seeking information and creating a network of contacts, although the possibilities offered by the new media still are not used to their full extent.

Originality/Value: There has not been any research on this form of informal communication behavior of university employees conducted in Poland previous to the study described in this paper.

\section{Keywords}

Informal information behavior. Scholarly communication. Invisible colleges. Networks of contacts. Knowledge and information sharing. Social media. Science 2.0.

Dr hab. PIOTR TAFIŁOWSKI, adiunkt w Katedrze Informatologii na Wydziale Dziennikarstwa, Informacji i Bibliologii Uniwersytetu Warszawskiego. W pracy naukowej i dydaktycznej zajmuje się bibliologia historyczna, dziejami komunikacji spotecznej oraz zagadnieniami informatologii. Najważniejsze nowe publikacje: Rejestracja rękopiśmiennych i drukowanych poloników w zbiorach zagranicznych - problem wciaż otwarty, Roczniki Biblioteczne 58 (2014) [druk 2015], 87-100; Anti-Turkish Literature in 15 $5^{\text {th }}$-16 ${ }^{\text {th }}$ Century Europe, Tarih Incelemeleri Dergisi, XXX/1 (2015), 231-280; Antyturecka korespondencja Macieja Korwina i Sykstusa IV : przyczynek do dziejów propagandy w stosunkach międzynarodowych w późnym średniowieczu, Zeszyty Naukowe Uniwersytetu Jagiellońskiego. Prace Historyczne, 143 (2016), 1, 37-55.

\author{
Kontakt $z$ autorem: \\ p.tafilowski@gmail.com \\ Katedra Informatologii \\ Wydziat Dziennikarstwa, Informacji i Bibliologii \\ Uniwersytet Warszawski \\ ul. Nowy Świat 69 \\ 00-927 Warszawa
}

